\title{
Induction of Malic Enzyme and of Oxalacetate Decarboxylase in Three Lactic Acid Bacteria
}

\author{
By HELENE A. NATHAN* \\ Department of Bacteriology, Rutgers, The State University, New Brunswick, \\ New Jersey, U.S.A.
}

\section{SUMMARY}

The presence of inducible, DPN-specific malic enzymes have been demonstrated in Lactobacillus plantarum, L. casei and Streptococcus faecalis. Of 30 compounds tested, only L-malate induced the synthesis of malic enzyme in $L$. plantarum.

The possibility that the malic enzymes of these three organisms are bifunctional proteins which have separate sites to decarboxylate oxalacetate has been excluded. In addition to L-malate, three compounds, oxalacetate, acetoacetate and $\alpha$-ketoglutarate, induce the synthesis of oxalacetate decarboxylase even though they cannot induce the synthesis of malic enzyme. The oxalacetate decarboxylation system consists of an oxalacetate decarboxylase and an oxalacetate permease. Malate can induce the synthesis of only oxalacetate decarboxylase and not oxalacetate permease.

\section{INTRODUCTION}

It has been suggested that both malic enzyme activity (L-malate + DPN $\rightarrow$ pyruvate $+\mathrm{DPNH}+\mathrm{H}^{+}+\mathrm{CO}_{2}$ ) and oxalacetate decarboxylase activity (oxalacetate $\stackrel{\mathrm{Mn}++}{\longrightarrow}$ pyruvate $+\mathrm{CO}_{2}$, not oxalacetate $\stackrel{\mathrm{ATP}}{\rightleftarrows}$ phosphoenopyruvate $+\mathrm{CO}_{2}$ ) of Lactobacillus plantarum (arabinosus) are located on the same protein (Korkes \& Ochoa, 1948). These investigators used the term 'bifunctional protein' for an enzyme protein which can catalyse two separate reactions, which occur at different sites on the same protein. This concept distinguishes a 'bifunctional protein' from a poorly specific enzyme protein (which can accept more than one substrate at the same site). The assignment of the term 'bifunctional' to the malic enzyme of L. plantarum had depended upon the observation that acetone-dried preparations of $L$. plantarum, which had been grown in the presence of malate, contained both malic enzyme and oxalacetate decarboxylase activities whilst those grown in the absence of malate contained neither activity. During a study of compounds which might serve as inducers of the $L$. plantarum malic enzyme the possibility that oxalacetate decarboxylase might be independently induced, and so not be part of a bifunctional protein, was investigated.

\section{METHODS}

The organisms used were Lactobacillus plantarum 17-5 (ATCC 8014); L. casei (ATCC 7569); Streptococcus faecalis (ATCC 8043). The methods of Nathan (1961) were used for maintenance and preparation of inocula. Organisms to be used for

\footnotetext{
* Present address : Department of Biological_Sciences, Goucher College, Towson 4, Md., U.S.A.
} 
induction experiments were grown in 11 . batches in a modified Wright \& Skeggs (1944) medium. For $L$. casei and $S$. faecalis this medium was supplemented with either leucovorin $(0 \cdot 1 \mu \mathrm{g} . / \mathrm{ml}$.) or folic acid $(0 \cdot 1 \mu \mathrm{g} . / \mathrm{ml}$.) respectively.

For the detection of inducers, organisms were grown for $12 \mathrm{hr}$. at $36^{\circ}$ in 11 . mass cultures. Potential inducers $(1.5 \mathrm{mmole})$ were added to $50 \mathrm{ml}$. samples of the $12 \mathrm{hr}$. culture and the incubation at $36^{\circ}$ was continued for a further $3 \mathrm{hr}$. The organisms were then harvested by centrifugation, washed and resuspended so that a 1/10 dilution of the resultant suspension had an optical density of 0.4 when measured in a Klett-Summerson colosimeter equipped with a no. $42(420 \mathrm{~m} \mu)$ filter.

The amount of malic enzyme, or of oxalacetate decarboxylase, synthesized during the $3 \mathrm{hr}$. incubation period with a potential inducer, was subsequently assessed manometrically. For assay of malic enzyme, the main compartment of each Warburg vessel contained $\mathrm{MnCl}_{2}, 6.0 \mu$ mole; $\mathrm{MgSO}_{4} .7 \mathrm{H}_{2} \mathrm{O}, 6.0 \mu$ mole; $\mathrm{KCl}, 6.0 \mu$ mole; $1.2 \mathrm{ml}$. 0.1 M-phosphate buffer (pH 5.6); DL-malate, $0.23 \mathrm{mmole}$; in the side arm, $0.3 \mathrm{ml}$. suspension of organisms or acetone-dried organisms ( $20 \mathrm{mg}$. dry weight). The final volume was adjusted to $3.0 \mathrm{ml}$. with distilled water. The enzyme contents of organisms incubated with potential malic enzyme inducers were compared with that of organisms incubated with L-malate and with organisms incubated without addition of potential inducer.

For the assay of oxalacetate decarboxylase, the main compartment of each Warburg vessel contained $\mathrm{MnCl}_{2}, 6.0 \mu$ mole; $1.0 \mathrm{ml}$. 0.1 M-acetate buffer ( $\mathrm{pH} 4.5$ ); one side arm contained $0.3 \mathrm{ml}$. cell suspension of organisms or acetone-dried organisms. The final volume was adjusted to $3.0 \mathrm{ml}$. with distilled water. In all estimations of enzymic decarboxylation of oxalacetate, non-enzymic decarboxylation was deducted. The enzyme content of organisms incubated with potential oxalacetate decarboxylase inducers was compared with that of organisms which had been incubated with oxalacetate and with organisms incubated without addition of potential inducer.

For the detection of permeases, malic enzyme or oxalacetate activity of suspensions of organisms was compared with the activity of an acetone-dried preparation made from the same batch of organisms. It was assumed that acetone-drying would destroy any specific permeability barriers and that substrates would thus be freely diffusible.

\section{RESULTS}

\section{Malic enzyme}

\section{Experiments with Lactobacillus plantarum}

Of 30 compounds tested for ability to induce malic enzyme, only L-malate (which also serves as substrate for this enzyme), induced synthesis of appreciable amounts of malic enzyme (Table 1). There was thus a striking specificity for induction. An illustration of a typical experiment is given in Fig. 1. Compounds which showed more than traces of activity as inducers included as compared with $100 \%$ for L-malate: fumarate 3-8, mesaconate 3-10, DL-alanine 7, DL-methyl succinate 3-12, L-tartrate 1-3, D-tartrate 1-3, meso-tartrate 1-3, ketomalonate 1-3, DL- $\alpha$-methylglutarate 1-3. The apparent activity of fumarate may have been a reflexion of activity of malate produced by the reaction: fumarate $\rightarrow$ malate and not be indicative of activity of fumarate itself.

Acetone-dried preparations made from malate-grown Lactobacillus plantarum retained the ability to decarboxylate malate; i.e. the malic enzyme was stable to 
acetone-drying (Blanchard, Korkes, Del Campillo \& Ochoa, 1950). While not all of the $\mathbf{3 0}$ compounds previously tried as inducers were retested, no malic enzyme activity was found in acetone-dried preparations made from organisms grown with

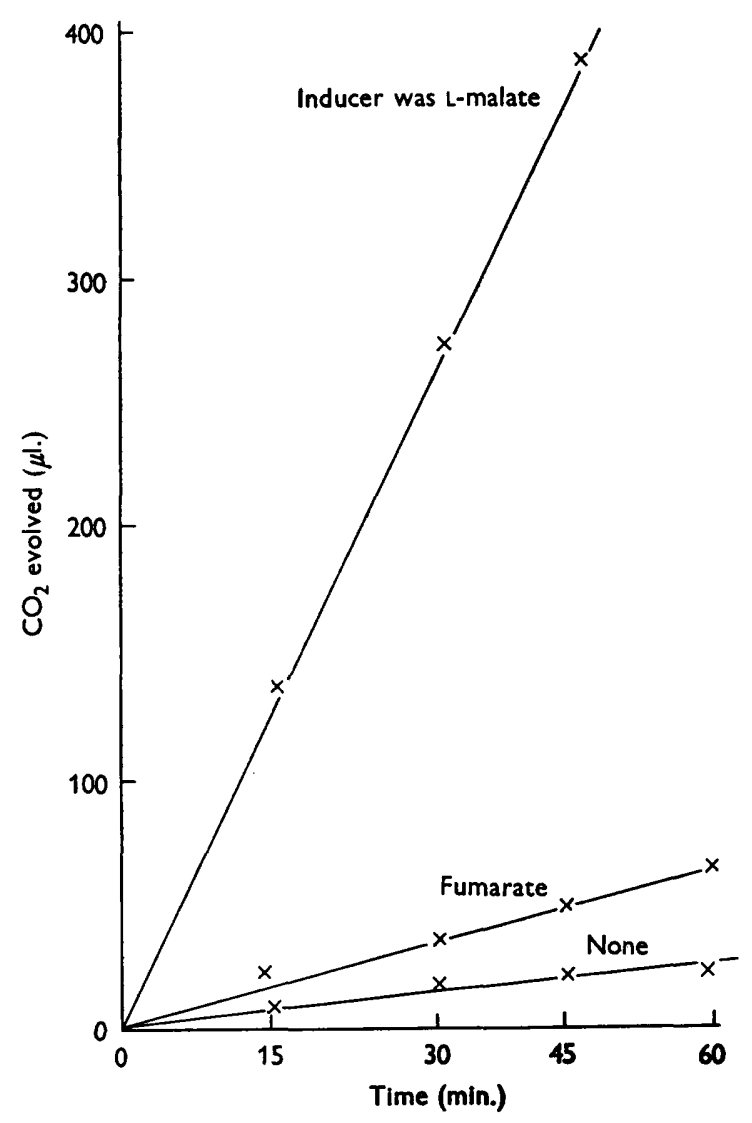

Fig. 1. Malic enzyme content of Lactobacillus plantarum grown in media containing potential inducers. Curves represent results obtained with suspensions of organisms which had been grown with different inducers during the final $3 \mathrm{hr}$. of growth.

oxalacetate, acetoacetate, or $\beta$-hydroxybutyrate as potential inducers. Evidence will be presented that these compounds do penetrate the intact cell and in these circumstances it would be possible that they might be able to induce malic enzyme. It is also possible that there is a malate permease whose induction can be demonstrated with intact organisms. Since active enzyme preparations (in which the specific permeability would be destroyed) from organisms grown with these substrates also do not show malic enzyme activity, it seems unlikely that an inducible malate permease exists.

\section{Oxalacetate decarboxylase}

This enzyme catalyses the irreversible conversion of oxalacetate to pyruvate. Full oxalacetate decarboxylase activity was shown by intact Lactobacillus plantarum grown with oxalacetate or acetoacetate, $90 \%$ activity for those grown with $\alpha$ - 
Table 1. Compounds tested for ability to induce synthesis of malic enzyme and oxalacetate decarboxylase in Lactobacillus plantarum

\begin{tabular}{|c|c|c|}
\hline \multirow[b]{2}{*}{ Compound } & \multicolumn{2}{|c|}{ Ability to induce synthesis of } \\
\hline & $\begin{array}{c}\text { Malic } \\
\text { enzyme }\end{array}$ & $\begin{array}{c}\text { Oxalacetate } \\
\text { decarboxylase }\end{array}$ \\
\hline L-Malate & $100^{*}$ & $100 \dagger$ \\
\hline Oxalacetate & $\mathbf{0}$ & $100 *$ \\
\hline Acetoacetate & $\mathbf{0}$ & 100 \\
\hline$\alpha$-Ketoglutarate & $\mathbf{0}$ & 90 \\
\hline Fumarate & $3-8$ & $\mathbf{0}$ \\
\hline Mesaconate & 3-10 & N.T.f \\
\hline DL-Alanine & 7 & N.T. \\
\hline DL-Methyl succinate & 3-12 & $1-3$ \\
\hline L-Tartrate & 1-3 & $\mathbf{0}$ \\
\hline D-Tartrate & 1-3 & 0 \\
\hline meso-Tartrate & $\mathbf{1 - 3}$ & $\mathbf{0}$ \\
\hline Ketomalonate & $1-3$ & N.T. \\
\hline DL- $\alpha$-Methylglutarate & $1-3$ & N.T. \\
\hline$\beta$-Hydroxybutyrate & $\mathbf{0}$ & $\mathbf{1}-\mathbf{3}$ \\
\hline
\end{tabular}

The following compounds could not induce synthesis of either enzyme : D-malate ; DL- $\alpha$-hydroxybutyrate; L-citramalate; DL-citramalate; succinate.

The following compounds could not induce synthesis of malic enzyme and were not tested for ability to induce oxalacetate decarboxylase: thiomalate; chloromalate; maleate; malonate; D-lactate; $\alpha$-methyl- $\alpha$-hydroxybutyrate; glutarate; $\beta$-hydroxy- $\beta$-methyl-glutarate; itaconate; tartronate; pyruvate.

* Ability of compounds to induce enzyme synthesis were compared with these reference compounds.

$\dagger$ Induces synthesis of the decarboxylase but not the permease.

$\ddagger$ Not tested.

ketoglutarate and $1-3 \%$ activity for those grown with either DL-methyl succinate or $\beta$-hydroxybutyrate (Tables 1 and 2). It was surprising to find that intact L. plantarum which had been grown with L-malate did not decarboxylate oxalacetate, especially since Korkes \& Ochoa (1948) had based their argument for the presence of a bifunctional protein on data which showed that acetone-dried preparations from malate-grown organisms contained oxalacetate decarboxylase, i.e. that ability to decarboxylate malate and oxalacetate were simultaneously induced. We therefore compared the oxalacetate decarboxylase activity of intact $L$. plantarum with that of acetone-dried preparations and found that while intact organisms grown with malate did not decarboxylate oxalacetate, acetone-dried preparations made from the same organisms did show oxalacetate decarboxylate activity. These data could be explained by the occurrence of an inducible oxalacetate permease.

\section{Oxalacetate permease}

Whole organisms of Lactobacillus plantarum grown with L-malate were unable to decarboxylate oxalacetate whereas acetone-dried preparations from the same batch of organisms decarboxylated oxalacetate readily. That is, L-malate induced the synthesis of malic enzyme and oxalacetate decarboxylase but not the permease which permits the penetration of oxalacetate into the intact organism.

Organisms grown with oxalacetate did not decarboxylate malate, nor did acetonedried preparations made from these organisms. Thus oxalacetate induced oxalacetate 
Table 2. Specificity for induction of oxalacetate decarboxylase, oxalacetate permease and malic enzyme in Lactobacillus plantarum and Streptococcus faecalis

\begin{tabular}{|c|c|c|c|}
\hline & \multicolumn{3}{|c|}{ Ability to induce } \\
\hline & \multicolumn{2}{|c|}{ Oxalacetate } & \multirow{2}{*}{$\begin{array}{c}\text { Malic } \\
\text { enzyme }\end{array}$} \\
\hline & Decarboxylase & Permease & \\
\hline Oxalacetate & + & + & $\mathbf{0}$ \\
\hline Acetoacetate & + & + & $\mathbf{0}$ \\
\hline$\alpha$-Ketoglutarate & + & + & $\mathbf{0}$ \\
\hline L-Malate & + & 0 & + \\
\hline
\end{tabular}

permease and oxalacetate decarboxylase but not malic enzyme, and malate induced oxalacetate decarboxylase and malic enzyme but not oxalacetate permease. It therefore seems highly unlikely that the malic enzyme and oxalacetate decarboxylase are part of one 'bifunctional protein'. Indeed the evidence for such a bifunctional protein, i.e. consistent simultaneous induction used as a criterion by the earlier workers (Korkes \& Ochoa, 1948), has been shown to be incomplete by the experiments presented here, since the evidence of Korkes \& Ochoa rested only on induction by malate and not on induction by oxalacetate.

Our results, summarized in Table 2, show that L-malate can induce malic enzyme and oxalacetate decarboxylase but not oxalacetate permease whilst oxalacetate, acetoacetate and $\alpha$-ketoglutarate can induce oxalacetate decarboxylase but not malic enzyme. Competence as inducer of oxalacetate permease seems to depend upon the presence of a free keto group. From these data, one may conclude that (a) oxalacetate decarboxylase and malic enzyme are separate enzymes and not part of a bifunctional protein, $(b)$ the oxalacetate decarboxylation system of intact Lactobacillus plantarum consists not only of an inducible decarboxylase but also of an inducible permease.

Experiments with Streptococcus faecalis and Lactobacillus casei

Illustrations of results are made with data from experiments done with Streptococcus faecalis. Since the same results were obtained from duplicate experiments done with Lactobacillus casei, these data are not reproduced here.

The presence of inducible malic enzymes in Streptococcus faecalis and Lactobacillus case $i$ was established by growing the organisms in the modified Wright \& Skeggs (1944) medium, or in this medium + DL-malate $(0 \cdot 1 \%, w / v)$. Suspensions of the resultant organisms which were grown in the presence of malate showed malic enzyme activity; thus the $S$. faecalis and $L$. casei malic enzymes were inducible.

The coenzyme requirements of the Streptococcus faecalis, Lactobacillus casei and $L$. plantarum malic enzymes were found to be DPN-specific. The experiment illustrated in Fig. 2 shows results obtained with acetone-dried $S$. faecalis. Because of imperfect removal of the endogenous coenzyme during acetone-drying, it was possible to demonstrate inhibition of this residual activity by added TPN (Fig. 2).

A survey of potential inducers of malic enzyme revealed that the specificity for the Streptococcus faecalis malic enzyme was at least as strict as for the Lactobacillus plantarum malic enzyme. The presence of inducible oxalacetate decarboxylase and oxalacetate permease and the separate induction of the oxalacetate system 


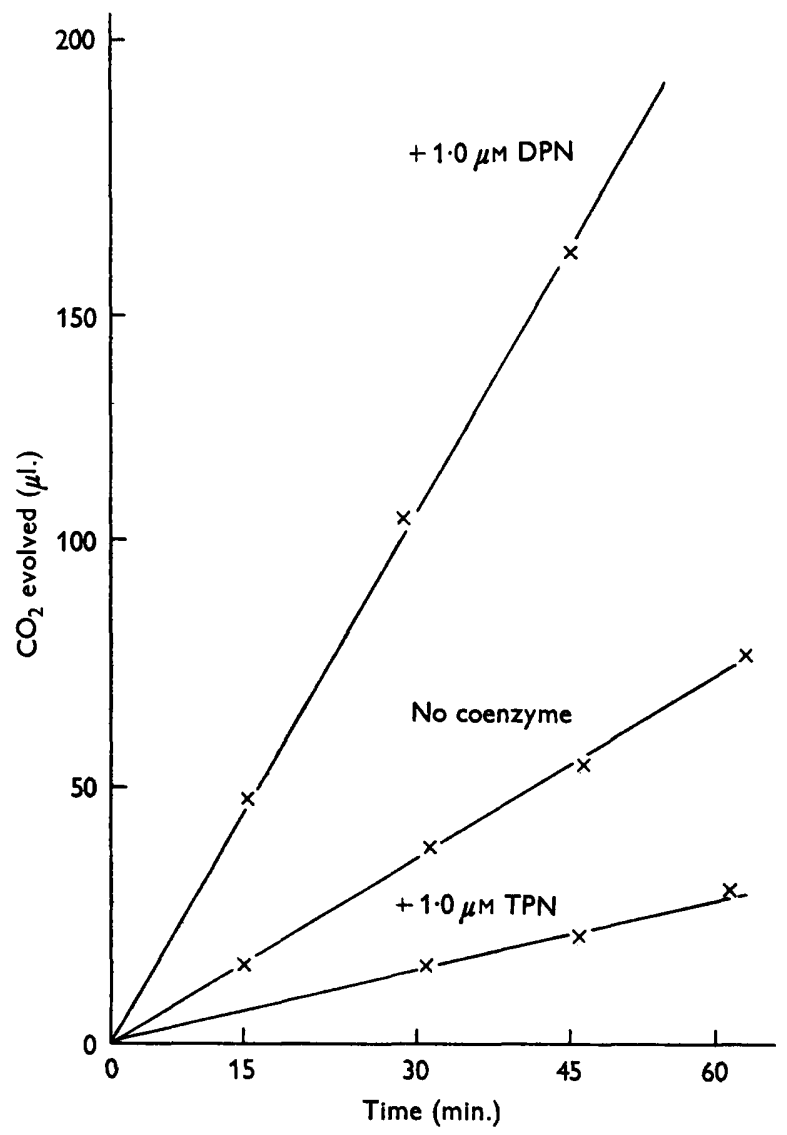

Fig. 2. Coenzyme specificity of the Streptococcus faecalis malic enzyme. Enzyme preparation used was acetone-dried cells.

and the malic enzyme described above for $L$. plantarum was also found to occur with the $S$. faecalis and $L$. casei enzymes.

I thank Professor W. W. Umbreit for his continued interest and advice during these studies, and Professor H. A. Barker and Dr A. C. Hulme, respectively, for generous gifts of L-citramalate and DL-citramalate.

\section{REFERENCES}

Blanchard, M. L., Korkes, S., Del Campillo, A. \& Ochoa, S. (1950). Function of biotin in the metabolism of Lactobacillus arabinosus. J. biol. Chem. 187, 875.

Korkes, S. \& OCHOA, S. (1948). Adaptive conversion of malate to lactate and carbon dioxide by Lactobacillus arabinosus. J. biol. Chem. 176, 463.

Nathan, H. A. (1961). Effect of nutritional deficiencies on synthesis of the inducible malic enzyme of Lactobacillus plantarum. Arch. Mikrobiol. 38, 107.

Wright, L. O. \& Skegas, H. R. (1944). Determination of biotin with Lactobacillus arabinosus. Proc. Soc. exp. Biol., N.Y. 56, 95. 